\title{
Korelasi antara Lama Pintas Jantung Paru dan Lama Bantuan Ventilasi Mekanis pada Pasien Pascabedah Pintas Arteri Koroner di Unit Perawatan Intensif Jantung RSUP Dr. Hasan Sadikin Bandung
}

\author{
Tias Diah Setiari, ${ }^{1}$ Reza Widianto Sudjud, ${ }^{2}$ Ike Sri Redjeki ${ }^{2}$ \\ ${ }^{1}$ Bagian Anestesi Rumah Sakit Umum Daerah Sukoharjo, \\ ${ }^{2}$ Departemen Anestesiologi dan Terapi Intensif \\ Fakultas Kedokteran Universitas Padjadjaran/RSUP Dr. Hasan Sadikin Bandung
}

\begin{abstract}
Abstrak
Pintas jantung paru (PJP) diperlukan untuk sebagian besar prosedur bedah pintas arteri koroner (BPAK). Fungsi paru dan oksigenasi menurun sekitar 2-90\% pada pasien pascabedah jantung dengan PJP. Ketergantungan terhadap ventilator setelah BPAK secara signifikan berhubungan dengan morbiditas dan mortalitas. Tujuan penelitian ini adalah mengorelasikan waktu PJP dengan lama bantuan ventilasi mekanis pada pasien BPAK. Penelitian ini merupakan analisis kohort retorospektif pada 43 pasien yang menjalani BPAK dengan PJP yang dirawat di Unit Perawatan Intensif Jantung RSUP Dr. Hasan Sadikin Bandung pada bulan Januari 2014 sampai Juni 2015. Lama PJP dibagi menjadi $\leq 90$ menit dan $>90$. Lama bantuan ventilasi mekanis terbagi menjadi $\leq 12$ jam dan $>12$ jam. Parameter yang dicatat pada penelitian ini adalah usia, berat badan, tinggi badan, indeks massa tubuh, lama PJP, waktu klem aorta, dan lama bantuan ventilasi mekanis. Analisis stastistik menggunakan uji korelasi Lambda, signifikan jika nilai $p<0,05$. Penelitian ini menunjukkan korelasi yang cukup kuat antara waktu PJP dan lama bantuan ventilasi mekanis setelah BPAK dengan korelasi positif $(0,545)$ dan signifikan $(\mathrm{p}<0,05)$. Simpulan penelitian ini adalah semakin lama waktu PJP berkorelasi dengan memanjangnya lama bantuan ventilasi mekanis.
\end{abstract}

Kata kunci: Bedah pintas arteri koroner, pintas jantung paru, ventilasi mekanis

\section{Correlation between Cardiopulmonary Bypass Time and Mechanical Ventilation Duration in Coronary Artery Bypass Post-Surgery Patients at Cardiac Intensive Care Unit of Dr. Hasan Sadikin General Hospital Bandung}

\begin{abstract}
Cardiopulmonary bypass (CPB) is necessary for majority of procedures in coronary artery bypass grafting (CABG) surgery. Pulmonary function is affected by CBP-triggered inflammatory cascade effects. Lung functions and oxygenation are impaired in $20 \%$ to $90 \%$ of CPB cardiac surgery patients. Ventilator dependency following CABG is often associated with significant morbidity and mortality. This study aimed to correlate the CPB time and mechanical ventilation duration after coronary artery bypass graft. This was a retrospective analysis cohort study on 43 consecutive patients undergoing CABG on CPB admitted to cardiac intensive care unit between January 2014 and June 2015 in Dr. Hasan Sadikin General Hospital Bandung. The CPB time was divided into $<90$ minutes and $\geq 90$ minutes. Duration of mechanical ventilation was defined as $\leq 12$ hours and $\geq 12$ hours of ventilation. Parameters recorded in this study were age, weight, height, body mass index, CPB time, aortic cross-clamp time, and mechanical ventilation duration. Statistical analysis was performed using Lambda correlation, which is significant if $\mathrm{p}$ value $<0.05$. This study showed moderate correlation between CPB time and mechanical ventilation duration after CABG surgery with a positive $(0.545)$ and significant correlation $(\mathrm{p}<0.05)$. Conclusion of this research is longer CPB time correlates with prolonged mechanical ventilation
\end{abstract}

Key words: Cardiopulmonary bypass time, coronary artery bypass grafting, mechanical ventilation

Korespondensi: Tias Diah Setiari, dr., SpAn, Bagian Anestesi Rumah Sakit Umum Daerah Sukoharjo, Jl. Muwardi No. 71, Gayam, Kec. Sukoharjo, Kabupaten Sukoharjo, Jawa Tengah 57514, Tlpn. 0271-593118, Email tiasdiah@gmail.com 


\section{Pendahuluan}

Bedah pintas arteri koroner (BPAK) merupakan prosedur pembedahan yang dilakukan pada pasien penyakit arteri koroner (PAK). Pasien pascabedah pintas arteri koroner pada umumnya dapat bernapas secara spontan segera setelah pasien pulih dari obatobat anestesi. Mode ventilasi seharusnya memiliki pengaruh kecil dalam mengambil keputusan untuk ekstubasi. Penelitian awal mempertimbangkan bahwa pasien yang menggunakan ventilasi mekanik pascabedah jantung akan mengalami stabilisasi sistem kardiovaskular dan sistem organ lainnya dari pengaruh respons inflamasi sebelumnya yang disebabkan oleh mesin pintas jantung paru. ${ }^{1,2}$

Fungsi paru dan oksigenasi mengalami penurunan sebanyak $20-90 \%$ pada pasien pascabedah pintas arteri koroner dengan menggunakan mesin pintas jantung paru. Penggunaan bantuan ventilasi mekanis jangka panjang pascabedah pintas arteri koroner merupakan salah satu komplikasi pascaoperasi yang dapat meningkatkan morbiditas dan mortalitas, sebanding dengan peningkatan biaya rawat dan menurunkan kualitas hidup. Suatu penelitian menyatakan $2,6-22,7 \%$ pasien pascabedah jantung terbuka memerlukan ventilasi mekanis jangka panjang dan sekitar 7\% pasien dilakukan reintubasi Penelitian terbaru memfokuskan pada identifikasi faktor risiko preoperatif, intraoperatif, serta pascaoperatif yang berhubungan dengan lama bantuan ventilasi mekanis yang dapat memprediksi prognosis dan hasil luaran pasien BPAK. ${ }^{2-6}$

Penelitian menyatakan bahwa mesin PJP menyebabkan perubahan pada paru yang meliputi elastisitas, daya regang dan resistensi, serta perubahan permeabilitas pada pembuluh darah paru. Disfungsi paru pascaoperasi jantung terbuka memiliki etiologi yang sangat kompleks, terutama disebabkan oleh respons inflamasi sistemik yang dicetuskan oleh pintas jantung paru dan meningkatkan permeabilitas endotel paru. Peningkatan pelepasan mediator inflamasi disebabkan oleh interaksi antara darah dan permukaan benda asing dari mesin pintas jantung paru. ${ }^{7}$ Penelitian ini bertujuan mengorelasikan antara lama pintas jantung paru dan lama bantuan ventilasi mekanis pada pasien pascabedah pintas arteri koroner.

\section{Subjek dan Metode}

Penelitian ini dilakukan setelah mendapat persetujuan dari Komite Etik Penelitian Kesehatan Fakultas Kedokteran Universitas Padjadjaran/RSUP Dr. Hasan Sadikin Bandung. Penelitian dilakukan di RSUP Dr. Hasan Sadikin Bandung, periode bulan April dan Mei 2016 dengan kriteria inklusi adalah semua pasien dewasa pascabedah pintas arteri koroner yang dirawat di unit perawatan intensif jantung menggunakan bantuan ventilasi mekanis dengan fraksi ejeksi $>40 \%$. Kriteria eksklusi adalah pasien dengan penyakit paru preoperatif, hipertensi pulmoner berat, gagal jantung fungsional di atas kelas II, gagal ginjal preoperatif, indeks massa tubuh $>35 \mathrm{~kg} / \mathrm{m}^{2}$, serta operasi darurat atau ulangan. Kriteria pengeluaran adalah pasien meninggal atau reintubasi serta data tidak lengkap.

Penelitian ini merupakan deskriptif analitik secara kohort retrospektif. Data yang memenuhi kriteria inklusi dan tidak termasuk kriteria eksklusi diambil secara sekunder dari rekam medis pasien yang telah dirawat di unit perawatan intensif jantung. Lama penggunaan mesin pintas jantung paru dicatat yang dikategorikan menjadi $\leq 90$ menit dan $>90$ menit dan dicatat juga lama bantuan ventilasi mekanis yang dibagi menjadi $\leq 12$ jam dan $>12$ jam. Data numerik dinilai dengan uji normalitas menggunakan uji Shapiro Wilks, analisis statistik untuk data kategorik diuji dengan uji chi-square. Uji statistika untuk mencari korelasi untuk dua variabel kategorik menggunakan uji korelasi Lambda. Interpretasi hasil uji hipotesis berdasar atas kekuatan korelasi, arah korelasi dan nilai p, kekuatan korelasi (r) berdasar atas kriteri Guillford (1956) terdapat pada Tabel 1. Kriteria kemaknaan yang digunakan adalah nilai $p$, apabila $p \leq 0,05$ artinya signifikan atau bermakna secara statistika. Data yang diperoleh dicatat dalam formulir khusus, 
Tabel 1 Uji Hipotesis berdasar atas Kriteria Guilford

\begin{tabular}{cl}
\hline Kekuatan Korelasi & \multicolumn{1}{c}{ Interpretasi } \\
\hline $0,0-<0,2$ & Sangat lemah \\
$0,2-<0.4$ & Lemah \\
$0,4-<0,6$ & Sedang/moderat \\
$0,6-<0,9$ & Kuat \\
$0,9-1,0$ & Sangat kuat \\
\hline
\end{tabular}

kemudian diolah melalui program statistical product and service solution (SPSS) versi 21.0 for windows.

\section{Hasil}

Jumlah pasien pada penelitian ini adalah 43 orang yang dicatat berdasar atas rekam medis pasien. Karakteristik subjek penelitian berdasar atas usia, jenis kelamin, lama PJP dan lama klem aorta dapat dilihat pada Tabel 2.

Hasil korelasi analisis statistik korelasi Lamda antara variabel lama waktu PJP dengan lama bantuan ventilasi mekanis diperoleh nilai p sebesar 0,025, serta didapatkan nilai r untuk nilai korelasi berdasar atas kriteria Guilford sebesar 0,545 (Tabel 3).

Penelitian ini juga mencatat lama klem aorta (temuan lain) yang dihubungkan dengan lama bantuan ventilasi mekanis. Nilai koefisien korelasi (r) dari Tabel 3 diperoleh informasi bahwa arah korelasi positif dengan kekuatan korelasi yang sangat kuat. Analisis statistik Eta menunjukan bahwa nilai $r$ untuk nilai korelasi klem aorta sebesar 0,947 dan nilai $\mathrm{p}=0,0001$.

\section{Pembahasan}

Penggunaan ventilasi mekanis jangka panjang pascabedah pintas arteri koroner masih lazim terjadi di unit perawatan intensif dan merupakan komplikasi pascaoperasi yang memiliki prognosis buruk terhadap hasil luaran pasien. Hal ini berkaitan dengan peningkatan morbiditas dan mortalitas, serta berdampak terhadap lama inap dan biaya perawatan rumah sakit. Penelitan menunjukkan angka mortalitas meningkat $40 \%$ jika dibanding dengan pasien yang dilakukan ekstubasi dini. Penelitian juga menyatakan bahwa kematian yang disebabkan oleh komplikasi respirasi lebih sering terjadi pada pasien pascabedah pintas arteri koroner dibanding dengan penyebab yang berasal dari jantung. Identifikasi faktor risiko dalam penggunaan bantuan ventilasi mekanis jangka panjang merupakan hal yang sangat penting sehingga pasien dengan risiko tinggi dapat dioptimalkan preoperatif untuk meminimalkan komplikasi ini. ${ }^{8-10}$

Pada era awal dilakukannya BPAK, pasien pascaoperasi akan diberikan bantuan ventilasi

Tabel 2 Karakteristik Subjek Penelitian

\begin{tabular}{|c|c|c|c|}
\hline Variabel & n (\%) & Rata-rata (SD) & Median \\
\hline Usia (tahun) & & $53,976(8,087)$ & 55 \\
\hline \multicolumn{4}{|l|}{ Jenis kelamin } \\
\hline Laki-laki & $34(79 \%)$ & & \\
\hline Perempuan & $9(21 \%)$ & & \\
\hline Lama klem aorta (menit) & & $77,348(30,368)$ & 68 \\
\hline \multicolumn{4}{|l|}{ PJP (menit) } \\
\hline$\leq 90$ & $11(26 \%)$ & & \\
\hline$>90$ & $32(74 \%)$ & & \\
\hline \multicolumn{4}{|c|}{ Lama bantuan ventilasi mekanis (jam) } \\
\hline$\leq 12$ & $8(19 \%)$ & & \\
\hline$>12$ & 35 (81\%) & & \\
\hline
\end{tabular}


Tabel 3 Analisis Korelasi Lama Waktu PJP dan Klem Aorta (Temuan Lain) dengan Lama Bantuan Ventilasi Mekanis

\begin{tabular}{lll}
\hline \multicolumn{1}{c}{ Variabel } & r & Nilai p \\
\hline Korelasi lama waktu PJP dengan lama bantuan ventilasi mekanis & 0,545 & $0,025^{*}$ \\
Korelasi klem aorta dengan lama bantuan ventilasi mekanis & 0,947 & $0,000^{*}$ \\
\hline
\end{tabular}

Keterangan: nilai kemaknaan $\mathrm{p}<0,05$. Tanda * menunjukkan signifikan atau bermakna secara statistika. r: koefisien korelasi

mekanis jangka panjang untuk stabilisasi pascaoperasi. Kemajuan dalam bidang pembedahan dan anestesi lebih diarahkan untuk melakukan ekstubasi sedini-dininya setelah menjalani prosedur BPAK karena secara fisiologis pasien dapat bernapas secara spontan segera setelah efek dari obat anestesi hilang. Hasil yang optimal dipengaruhi oleh kerja tim antardisiplin baik pembedah, anestesi, serta staf perawatan intensif. ${ }^{4}$

Bantuan ventilasi mekanis jangka panjang sering terjadi pada pasien risiko tinggi yang dapat secara mudah diidentifikasi preoperatif atau saat pasien tiba di unit perawatan intensif pascaoperasi. Penelitian sebelumnya berupaya untuk mengenali berbagai faktor risiko untuk memprediksi keterlambatan ekstubasi pada pasien pascaoperasi jantung. Sekitar 2,6-22,7\% pasien pascaoperasi jantung membutuhkan bantuan ventilasi mekanis jangka panjang. Belum terdapat konsensus tentang definisi yang tetap dari penggunaan bantuan ventilasi mekanis jangka panjang. Penelitian sebelumnya menggunakan beberapa definisi yang bervariasi mulai dari waktu ekstubasi lebih dari 24 jam hingga lebih dari 7 hari. ${ }^{4,11}$

Penelitian menunjukkan terdapat beberapa hal yang penting dalam memprediksi indikator keterlambatan ekstubasi pada pasien yang menjalani BPAK. Penelitian London $\mathrm{dkk} \cdot{ }^{12}$ pada pasien yang menjalani operasi jantung terbuka menunjukkan bahwa usia tua dan penggunaan agen inotropik merupakan faktor risiko yang memperpanjang lamanya ekstubasi. London dkk. $^{12}$ juga menyatakan bahwa lama waktu $<10$ jam ditentukan sebagai ekstubasi dini, sedangkan penelitian retrospektif Arom dkk. ${ }^{13}$ pada pasien BPAK, ekstubasi dini ditetapkan dengan parameter waktu $<12$ jam, dilaporkan juga bahwa usia, jenis kelamin, penggunaan diuretik preoperatif dan penyakit jantung kongestif atau angina tidak stabil merupakan prediktor keterlambatan ekstubasi. Penelitian kohort oleh Cishalgi dkk. ${ }^{14}$ pada pasien BPAK menyatakan bahwa bedah jantung ulang, lamanya PJP, transfusi intraoperatif lebih dari 4 labu RBC (red blood cell) atau FFP (fresh frozen plasma), dan fraksi ejeksi $<40 \%$ merupakan faktor risiko independen untuk keterlambatan ekstubasi dengan parameter yang digunakan untuk keterlambatan ekstubasi adalah $>12$ jam. Penelitian retrospektif lainnya pada pasien BPAK menyatakan bahwa gagal jantung fungsional di atas kelas 2, hemodialisis, usia, berkurangnya $\mathrm{FEV}_{1}$, dan IMT lebih dari 35 $\mathrm{kg} / \mathrm{m}^{2}$ merupakan faktor yang meningkatkan risiko memanjangnya penyapihan ventilasi mekanis dengan parameter waktu $>72$ jam. ${ }^{11}$

Banyak faktor yang dapat berpengaruh dalam lamanya bantuan ventilasi mekanis, baik preoperasi, intraoperasi, dan pascaoperasi. Penelitian ini difokuskan pada salah satu faktor prediktor intraoperatif, yaitu lama PJP untuk melihat korelasi antara lama PJP secara khusus dan lama bantuan ventilasi mekanis dengan menyingkirkan faktor-faktor yang dapat memengaruhi lamanya bantuan ventilasi mekanis.

Pada penelitian bivariat ini dilakukan uji korelasi antara dua kelompok variabel, pada pasien dengan lama waktu PJP $\leq 90$ dan $>90$ menit terhadap kelompok lama bantuan ventilasi mekanis $\leq 12$ jam dan $>12$ jam, didapatkan korelasi yang signifikan secara statistika antara lama PJP dan lama bantuan ventilasi mekanis dengan nilai $\mathrm{p}=0,025$ dan nilai koefisien korelasi sebesar 0,545 yang 
menunjukkan arah korelasi positif dengan kekuatan korelasi yang cukup kuat. Parameter waktu yang digunakan dari lama PJP adalah $>90$ menit berkorelasi terhadap lamanya bantuan ventilasi mekanis dengan parameter waktu $>12$ jam. Lama PJP dapat meningkatkan kemungkinan terjadi disfungsi jantung dan memperburuk oksigenasi yang dari mulanya sudah tidak adekuat karena berkaitan dengan penurunan fungsi jantung. ${ }^{14}$

Mesin PJP merupakan suatu sirkulasi nonfisiologis yang memengaruhi perfusi jaringan perifer, terutama ketika digunakan dalam waktu yang lama. Durasi PJP menyebabkan trauma pada sel darah yang mengakibatkan perubahan permeabilitas membran kapiler yang memiliki dampak terhadap anoksia jaringan dan komplikasi paru. Mesin PJP menyebabkan respons inflamasi sistemik yang bervariasi dan berpotensial berbahaya terhadap jantung pasien. Hal ini disebabkan oleh kontak sel darah dengan permukaan benda asing dan mengakibatkan aktivasi komplemen, sitokin, endotelin, endotoksin, neutrofil, adhesi molekul, sel mast, dan mediator inflamasi multipel yang dapat menyebabkan kegagalan respirasi. ${ }^{14}$

Fungsiparudipengaruhi oleh mesin PJPyang menyebabkan pelepasan mediator inflamasi, radikal bebas, protease, leukotrien, serta asam arakidonat. Peningkatan pelepasan mediator yang diproduksi selama PJP menyebabkan peningkatan permeabilitas paru, sel inflamasi intersisial, cairan dan akumulasi protein yang menyebabkan mikroatelektasis, peningkatan pintas pulmoner, penurunan produksi surfaktan, pengurangan daya regang, dan peningkatan resistensi paru. Keseluruhannya menyebabkan peningkatan beban paru pascaoperasi. ${ }^{6}$

Respons inflamasi terhadap mesin PJP dan kerusakan iskemik paru telah dipertimbangkan sebagai penyebab utama kegagalan pernapasan pascaoperasi jantung dan telah dilaporkan dari beberapa penelitian keberhasilan mengurangi kerusakan paru setelah PJP dengan mengontrol respons inflamasi atau iskemik pulmoner, namun hanya sedikit pengobatan atau strategi yang telah digunakan dalam praktik klinis. Perkembangan BPAK tanpa menggunakan mesin PJP memberikan kesempatan kepada peneliti untuk mengevaluasi efek PJP pada pasien dengan prosedur pembedahan yang sama. ${ }^{15}$

Kontak elemen darah dengan permukaan dari mesin PJP mengaktivasi neutrofil polimorfonuklear (PMN). Aktivasi ini disebabkan oleh pelepasan mediator proinflamasi berupa IL-1, $-2,-6,-8$, dan TNF $\alpha$. Komplemen (terutama c3 dan c5a), platelet activating factor $(\mathrm{PAD} \mid \mathrm{F})$, dan LTB4 juga merupakan mediator inflamasi penting pada proses ini. Adhesi permukaan molekul CD18 dan CD11b pada permukaan sel neutrofil mencetuskan adhesi dari neutrofil itu sendiri di ligan tertentu (ICAM-1) yang terdapat pada endotel paru. Neutrofil ini menyebabkan dilepasnya enzim proteolitik spesifik (elastase, collagenase) dan radikal bebas oksigen yang masuk ke dalam sirkulasi sistemik dan merusak parenkim paru secara lokal melalui kerusakan pada sel dan jaringan. ${ }^{16}$

Pada penelitian ini juga didapatkan data yang menunjukkan korelasi antara lama waktu klem aorta dan lama bantuan ventilasi mekanis $(p=0,0001$ dan $r=0,947)$. Hal ini menunjukkan korelasi yang signifikan dengan arah korelasi positif dan sangat kuat antara klem aorta dan bantuan ventilasi mekanis pada pasien pascabedah pintas arteri koroner.

Pada penelitian ini lama klem aorta memiliki korelasi yang sangat kuat, sedangkan lama penggunaan mesin PJP memiliki korelasi yang moderat/cukup kuat terhadap lama bantuan ventilasi mekanis pada pasien pascabedah pintas arteri koroner. Jansen dkk. ${ }^{17}$ menyatakan bahwa terdapat peningkatan signifikan C3a dan elastase setelah digunakan mesin PJP dan semakin meningkat jumlahnya setelah dilepasnya klem aorta. Hal ini berhubungan dengan peningkatan leukotrien B4 (eicosanoid yang menginduksi kebocoran kapiler) dan tissue plasminogen activator (yang meningkatkan fibrinolisis). ${ }^{18}$

Lama waktu klem aorta juga merupakan salah satu faktor risiko yang memengaruhi 
lama penggunaan bantuan ventilasi mekanis pada pasien BPAK. Ketika aorta di klem, organ seperti otak, jantung, paru, dan ginjal tidak mendapatkan oksigenasi adekuat dan dapat terjadi iskemia. Namun, ketika klem dibuka terjadi reperfusion injury dan komponen dari respons inflamasi terlepas ke dalam sirkulasi yang mengakibatkan systemic inflammatory response syndrome (SIRS). ${ }^{19}$

Pada saat dilakukan klem aorta, jumlah neutrofil dalam darah di atrium kanan dan kiri meningkat. Setelah klem dilepas dan aliran darah kembali ke pembuluh darah paru, neutrofil di atrium kanan meningkat, namun di atrium kiri menurun yang menggambarkan bahwa neutrofil terperangkap di kapiler paru. Penelitian Tonz dkk. ${ }^{20}$ menyatakan terdapat korelasi positif antara konsentrasi plasma elastase (pengukur aktivasi neutrofil) dan indeks respirasi serta pintas intrapulmoner. Produk dari lipid peroksidasi dinilai dari reaksi asam tiobarbiturat yang mencapai puncak setelah klem aorta dilepas. Hal ini mengimplikasikan hubungan langsung antara neutrofil yang terperangkap pada kapiler paru dan radikal bebas oksigen peroksidase dari membran lipid. Kerusakan akibat reperfusi setelah iskemia mengakibatkan pembentukan radikal bebas oksigen dan dapat juga berkontribusi dalam pembentukan lipid peroksidase dalam waktu yang sama.

Reperfusion injury menginduksi sitokin yang melewati sirkulasi paru dan mengaktivasi endotel dan leukosit yang bermigrasi dari pembuluh darah pulmoner ke ruang interstitial dan alveolar serta memproduksi sitokin dan reactive oxygen species (ROS) yang menyebabkan inflamasi lokal dan acute respiratory distress syndrome (ARDS). Terdapat anafilaktosin $\mathrm{C} 3 \mathrm{a}$ dan $\mathrm{C} 5 \mathrm{a}$ meningkatkan tonus pembuluh darah dan juga peningkatan permeabilitas kapiler paru dan mengaktivasi sel mast untuk melepas histamin yang merusak paru lebih berat. Leukosit teraktivasi juga lepas ke dalam sirkulasi sistemik dan bersama-sama dengan ARDS menginduksi hipoksemia yang berkontribusi terjadi kerusakan organ lebih jauh melalui lepasnya ROS dan elastase yang juga meningkatkan permeabilitas mikrovaskular. $^{21}$

Penting untuk diketahui bahwa penyebab kegagalan paru setelah dilakukan operasi jantung dengan keterlibatan mesin PJP adalah multifaktorial. Faktor pasien ditambah dengan efek langsung mesin PJP berdampak terhadap fungsi paru pada kondisi pascaoperasi. ${ }^{22}$

\section{Simpulan}

Lama waktu PJP memiliki korelasi dengan lama bantuan ventilasi mekanis pada pasien pascabedah pintas arteri koroner.

\section{Daftar Pustaka}

1. Nozawa E, Azeka E, Ignêz ZM, Feltrim $\mathrm{Z}$, Auler JO. Factors associated with failure of weaning from long-term mechanical ventilation after cardiac surgery. Int Heart J. 2005;46(5):819-31.

2. Faritous. ZS, Aghdaie N, Tazdanian F, Azarfarin R, Dabbagh A. Perioperatif risk factors for prolonged mechanical ventilation and tracheostomy in women undergoing coronary artery bypass graft with cardiopulmonary bypass. Saudi J Anaesth. 2011;5(2):167-9.

3. Rezaianzadeh A, Maghsoudi B, Tabatabaee T, Keshavarzi S, Bagheri Z, dkk. Factors associated with extubation time in coronary artery bypass grafting patients. Peer J. 2015;3:1-11.

4. Piotto RF, Ferreira RB, Colosimo FC, Silva GS, Sousa AG, Braile DM. Independent predictors of prolonged mechanical ventilation after coronary artery bypass surgery. Rev Bras Cir Cardiovasc. 2012;27(4):520-8.

5. Thomas LH, Yared JP, Adi A. Postoperatif respiratori care. Dalam: Kaplan JA, Reich D, Savino JS, penyunting. Kaplan's cardiac anesthesia. Edisi ke-6. Missouri: Elsevier Saunders; 2011. hlm. 1046-60.

6. Rodrigues CD, Oliveira RA, Soares OM, Figueiredo LC, Sebastião Araújo, Dragosavac D. Lung injury and mechanical ventilation in cardiac surgery: a review. Rev Bras Cir Cardiovasc. 2010;22:4. 
7. Grocott HP, Smith MS, Mangano CT. Cardiopulmonary bypass management and organ protection. Dalam: Kaplan JA, Reich D, Savino JS, penyunting. Kaplan's cardiac anesthesia. Edisi ke-6. Missouri: Elsevier Saunders; 2011. hlm. 862-4.

8. Natarajan K, Patil S, Lesley N, Ninan B. Predictors of prolonged mechanical ventilation after on-pump coronary artery bypass grafting. Ann Card Anaesth. 2006;9:31-6.

9. Piotto RF, Maia LN, Machado MN, Orrico SP. Effects of the use of mechanical ventilation weaning protocol in the coronary care unit: randomized study. Rev Bras Cir Cardiovasc. 2011;26(2):213-21.

10. Tobias JD. Is there an optimal mode of ventilation following cardiac surgery? Saudi J Anesth. 2011;5(2):121-2.

11. Totonchi Z, Baazm F, Chitsazan M, Seifi S, Chitsazan MN. Predictors of prolonged mechanical ventilation after open heart surgery. J Cardiovasc Thorac Res. 2014;6(4):211-6.

12. London MJ, Shroyer AL, Coll JR, MaWhinney S, Fullerton DA, Hammermeister KE. et al. Early extubation following cardiac surgery in a veterans population. Anesthesiology. 1998;88:1447-58.

13. Arom KV, Emery RW, Petersen RJ, Schwartz M. Cost-effectiveness and predictors of early extubation. Ann Thorac Surg. 1995;60(1):127-32.

14. CislaghiF,CondemiAM,CoronaA.Predictors of prolonged mechanical ventilation in a cohort of 3,269 CABG patients. Minerva Anestesiol. 2007;73:615-21.

15. Imura $H$, Caputo $M$, Lim $K$, Ochi $M$, Suleiman S, Shimizu K, dkk. Pulmonary injury after cardiopulmonary bypass: Beneficial effects of low-frequency mechanical ventilation. J Thorac Cardiovasc Surg. 2009;137:15307.

16. ClarkSC.Lunginjuryaftercardiopulmonary bypass. Perfusion. 2006;21:225-8.

17. Jansen NJ, van $\mathrm{OW}$, van $\mathrm{VM}$, et al. The role of different types of corticosteroids on the inflammatory mediators in cardiopulmonary bypass. Eur J Cardiothorac Surg 1991;5:211-217.

18. Moitra VK, Sladen RN. Cardiopulmonary bypass and the lung. Dalam: Gravlee GP, Davis RF, Stammers AH, Ungerleider RM, penyunting. Cardiopulmonary bypass: principles and practice. Edisi ke3. Philadelphia: Lippincott Williams \& Wilkins; 2008. hlm. 311-20.

19. Steidl S. the adverse effects of the cardiopulmonary bypass machine. Liberty University. 2011;1(1):1-35.

20. Tönz M, Mihaljevic T, von Segesser LK, Fehr J, Schmid ER, Turina MI. Acute lung injury during cardiopulmonary bypass: are the neutrophils responsible?. Chest. 1995; 108:1551-6.

21. Katseni K, Chalkias A, Kotsis T, Dafnios N, Arapoglou V, Kaparos G, dkk. The effect of perioperatif ischemia and reperfusion on multiorgan dysfunction following abdominal aortic aneurysm repair. Biomed Res Int. 2015;2015:1-11.

22. Karalapillai D, Story D, Hart GK, Bailey M, Pilcher D, Cooper DJ, dkk. Postoperatif hypothermia and patient outcomes after elective cardiac surgery. Anaesthetists. 2013;68(6):605-11. 